\title{
Photophysical, electrochemical, and DFT studies of the novel azacrown- bridged dinuclear ruthenium dye sensitizers for solar cells
}

\author{
Veikko Uahengo $^{\mathrm{a}, *}$, Ping Cai ${ }^{\mathrm{b}}$, Johannes Naimhwaka ${ }^{\mathrm{a}}$, Ateeq Rahman ${ }^{\mathrm{a}}$, Likius S. Daniel ${ }^{\mathrm{a}}$, \\ Hanusha Bhakhoa ${ }^{c}$, Lydia Rhyman ${ }^{\mathrm{c}, \mathrm{d}}$, Ponnadurai Ramasami ${ }^{\mathrm{c}, \mathrm{d}, *}$ \\ a Department of Chemistry and Biochemistry, University of Namibia, 340 Mandume Ndemufayo Avenue, Windhoek 9000, Namibia \\ ${ }^{\mathrm{b}}$ College of Chemistry and Molecular Sciences, Wuhan University, Wuhan 430072, China \\ ' Computational Chemistry Group, Department of Chemistry, Faculty of Science, University of Mauritius, Réduit 80837, Mauritius \\ ${ }^{\mathrm{d}}$ Department of Chemical Sciences, University of Johannesburg, Doornfontein, Johannesburg 2028, South Africa
}

\section{A R T I C L E I N F O}

\section{Article history:}

Received 26 July 2019

Accepted 10 August 2019

Available online 16 August 2019

Keywords:

Bridging ligands

Charge transfer

DFT

Dinuclear ruthenium complex

Electronic coupling

\begin{abstract}
A B S T R A C T
A dinuclear ruthenium bipyridyl complex with 1,10-diaza-18-crown-6 bridging ligand was synthesized and characterized. Its photophysical and electrochemical properties were also studied. DFT computations were performed to complement the experimental investigations. Analysis of the results indicates that the path in which charges move from one metal center to the other is significant for effective electronic coupling. However, electron transfer between the two ruthenium centers is hindered by the azacrown bridging ligand, compared to the smooth electronic transfer reported for a related dye involving an azo bridging ligand.
\end{abstract}

(c) 2019 Elsevier Ltd. All rights reserved.

\section{Introduction}

Ruthenium bipyridyl-based complexes are receiving considerable attention, in the quest of converting solar energy into electricity [1-3]. This research interest is triggered by the depletion of fossil fuels which contribute to around $80 \%$ of global energy consumption [4]. The emission of carbon dioxide into the atmosphere due to the burning of fossil fuels is also entailing global warming and severe climate changes. This has prompted resource investments, toward alternative "green energy" sources with a view to meet the energy demand [2,3]. Dye-sensitized solar cells (DSSCs) based on ruthenium bipyridyl complexes emerged as alternatives to fossil fuels [3]. Several ruthenium bipyridyl derivatives $[2,5,6]$ have been explored since the seminal work of O'Regan and Grätzel [7] on the photocatalytic activities of prototypical complexes. Their relatively good chemical stability, broad metal-to-ligand charge transfer (MLCT) absorption bands, strong luminescence, and suitable ground and excited states potentials [8] make ruthenium bipyridyl-based complexes ideal candidates not only

\footnotetext{
* Corresponding authors at: Department of Chemistry and Biochemistry, University of Namibia, 340 Mandume Ndemufayo Avenue, Windhoek 9000, Namibia (V. Uahengo); Computational Chemistry Group, Department of Chemistry, Faculty of Science, University of Mauritius, Réduit 80837, Mauritius (P. Ramasami).

E-mail addresses: vuahengo@unam.na (V. Uahengo), p.ramasami@uom.ac.mu (P. Ramasami)
}

as dye-sensitizers but also in the field of catalysis $[9,10]$ and medicine [11-13]. Strong luminescent properties of the dye extend the light-harvesting ability of a DSSC, where the parts of the incident radiation from the wavelengths that the dye absorbs poorly are converted to wavelengths at which the dyes absorbs better, through either high-energy photons which are converted to lowenergy photons or the reverse; designated as down-conversion (DC) and up-conversion (UC), respectively [8].

For a DSSC to function efficiently and effectively, all components $\left(\mathrm{TiO}_{2}\right.$ nanoparticles, dye sensitizer, redox mediator, and counter electrode) constituting the system must play their roles adequately. The dye sensitizer is regarded as the key component which governs the photovoltaic performance of DSSCs [2]. Different strategies are adopted to optimize the performance of ruthenium bipyridyl-based complexes to fit specific functionalities, namely, employing different ancillary ligands [2], using light harvesting antennas which funnel their photonic excitation to the dye sensitizer modules [14,15], or designing spacers (bridging ligands) which separate photoactive terminals [16-18], among others. The role of bridging ligands is particularly attractive for they not only allow control over the spatial arrangement of the complexes but also provide an insight into the electronic coupling of the separated metal centers [19].

Dinuclear ligand-bridged mixed/homo-valent ruthenium bipyridyl complexes of the type $\left[\left\{\mathrm{L}_{n} \mathrm{M}\right\}(\mu-\mathrm{BL})\left\{\mathrm{ML}_{n}\right\}\right]^{n+}(\mathrm{M}=$ metal 
centers, $\mathrm{L}_{n}=$ ancillary terminal ligands, and $\mathrm{BL}=$ bridging ligand) account for several studies [20-29]. However, corresponding studies with bridging ligands based on aza-crown ethers, in particular, the 1,10-diaza-18-crown-6, are scarce in literature [30-33]. To the best of our knowledge, the X-ray crystal structure of only one homo-dinuclear ruthenium complex with a 1,10-diaza-18-crown6 derivative as bridging unit and terpyridine as an ancillary terminal ligand is known insofar (see Scheme 1) [30].

Further to our interest on novel dye sensitizers [23,24,34,35], we are herein reporting the synthesis of the first dinuclear azacrown-bridged homo-valent ruthenium bipyridyl complex, $\left[\left\{\mathrm{Ru}^{\mathrm{II}}(\mathrm{bpy})_{2}\right\}_{2}\left(\mu-\mathrm{BL}_{1}\right)\right]\left(\mathrm{PF}_{6}\right)_{4} \quad$ (bpy = bipyridine and $\mathrm{BL}_{1}=7,16-$ bis(4-(6-phenyl-[2,2'-bipyridin]-4-yl)benzyl)-1,4,10,13-tetraoxa7,16-diazacyclooctadecane) which is denoted as Dye $\mathbf{1}$ (see Scheme 2). Cyclic voltammetry, spectro-electrochemistry and density functional theory (DFT) method were employed to have an in-depth understanding into the metal-to-metal charge transfer (MMCT) occurring in Dye 1 via the 1,10-diaza-18-crown-6 bridge. DFT computations were also carried out on a related dye based on an azo bridge $\left[\left\{\mathrm{Ru}^{\mathrm{II}}(\mathrm{bpy})_{2}\right\}_{2}\left(\mu-\mathrm{BL}_{2}\right)\right]\left(\mathrm{ClO}_{4}\right)_{4}$, where $\mathrm{BL}_{2}=2,2^{\prime}-\{(\mathrm{E})-1$, 2-diazenediylbis[2,1-phenylenenitrilo(E)methylylidene]\}diphenol and $\mathrm{ClO}_{4}^{-}=$perchlorate (denoted as Dye 2; see Scheme 2), which was previously reported $[23,24]$. A comparative study was subsequently conducted between Dye 1 and Dye 2. The electronic communication effect between the two separate metal centers upon substitution of $\mathrm{BL}_{2}$ (azo bridge) for $\mathrm{BL}_{1}$ (azacrown bridge) on the electrochemical and photophysical activities of the complexes was probed.

\section{Methodology}

\subsection{Synthesis}

Dye 1 and its bridging ligand were synthesized according to the reported method [30], while Dye 2 [23,24] and its bridging ligand were synthesized according to our previous work [36,37].

Dye 1: ${ }^{1} \mathrm{H}$ NMR $\left(300 \mathrm{MHz}\right.$, Methanol- $d_{4}: \delta 8.70$ (s, $2 \mathrm{H} \mathrm{ArH} \mathrm{Apy}_{\mathrm{bpy}}$ ), 8.39 (s, $10 \mathrm{H} \mathrm{ArH}$ bpy), 8.15 (s, $4 \mathrm{H} \mathrm{ArH}_{\text {bpy }}$ ), 7.97 (d, J = 6.9 Hz, $10 \mathrm{H}$ $\mathrm{ArH}_{\text {bpy }}$ ), 7.65 (d, J=7.8 Hz, 4H ArH bpy $), 7.58$ (m, 6H ArH $\left.\mathrm{Arpy}_{\text {by }}\right), 7.42$ $\left(\mathrm{m}, 10 \mathrm{H} \mathrm{ArH}_{\text {benz }}\right), 7.00\left(\mathrm{~s}, 4 \mathrm{H}, \mathrm{ArH}_{\text {bpy }}\right), 3.86(\mathrm{~s}, 4 \mathrm{H}), 3.31$ (d, $\left.J=2.3 \mathrm{~Hz}, 4 \mathrm{H}, \mathrm{N}-\mathrm{CH}_{2}\right), 3.00$ (s, $\left.4 \mathrm{H}, \mathrm{ArH}_{\text {crow-eth }}\right), 2.89$ (s, $4 \mathrm{H}$ $\mathrm{ArH}_{\text {crow-eth }}$ ). Ligand 1 (Dye 1): ${ }^{1} \mathrm{H}$ NMR (300 MHz, Chloroform-d) $\delta$ 8.76-8.59 (m, 3H), 8.25-8.15 (m, 2H), $7.97(\mathrm{~d}, J=1.6 \mathrm{~Hz}, 1 \mathrm{H})$, 7.93-7.72 (m, 3H), 7.59-7.40 (m, 5H), $7.34(\mathrm{dd}, J=7.4,4.9 \mathrm{~Hz}$, 1H), 3.79 (s, 2H), 3.67 (d, J = 8.5 Hz, 8H), 2.89 (t, $J=5.9 \mathrm{~Hz}, 4 \mathrm{H}$ ), $1.34-1.19(\mathrm{~m}, 3 \mathrm{H})$.

\subsection{Computational details}

Reported X-ray crystals structures of related complexes $[30-32,29]$ together with those derived from ChemSpider database $[38,39]$ were used as initial guess structures to obtain the optimized geometries of Dye 1 and Dye 2. Full geometry optimizations of Dye 1 and Dye $\mathbf{2}$ were performed in the gas phase and in methanol $(\mathrm{MeOH})$ and acetonitrile $(\mathrm{MeCN})$ solvents [40,41]. Solvent computations were carried out using the conductor-like polarizable continuum model (CPCM) [42-44]. The DFT functional B3LYP [45-47] in conjunction with the $6-31 \mathrm{G}(\mathrm{d}, \mathrm{p})$ basis set for the $\mathrm{H}, \mathrm{C}, \mathrm{N}$, and $\mathrm{O}$ atoms [48] and the ECP LANL2DZ for Ru [49] were employed for all computations. The method [50-52] and solvation model $[28,29,52,53]$ were selected based on previous studies involving ruthenium complexes. Each $\mathrm{Ru}$ atom in the complex is in an oxidation state of +2 and hence, a charge of +4 was considered for both dyes. Geometry optimization was followed by analytic Hessian computation at the same level of theory, and the absence of negative Hessian eigenvalues confirmed the stationary points as minima on the potential energy hypersurfaces. The UVVis spectra were obtained from the time-dependent DFT (TDDFT) computations $[48,54,55]$ using the geometry optimized in $\mathrm{MeOH}$. The 70 lowest singlet energy optical excitations were calculated using the TD-DFT method. HOMO-LUMO gap are also reported for the complexes optimized in MeCN. All DFT computations were performed using the GAUSSIAN 09 package [56] using resources provided by SEAGRID [57-61].

\section{Results and discussion}

\subsection{Structural properties}

In the absence of X-ray crystal structures for Dye $\mathbf{1}$ and Dye 2, their structures are herein predicted and characterized via the DFT and TD-DFT methods in view to complement the experimental findings. Two optimized structures 1a (Fig. 1) and $\mathbf{1 b}$ (Fig. S1) were modeled for Dye 1 based on the X-ray crystal structures of [Ru(tpy) $\left.\left(\mathrm{BL}_{0}\right)\right]\left(\mathrm{PF}_{6}\right)_{2}$ [31], $\left[\mathrm{Ru}(\mathrm{bpy})_{2}\left(\mathrm{BL}_{3}\right)\right]\left(\mathrm{PF}_{6}\right)_{2}$ [32] and $\left[\{\mathrm{Ru}(\mathrm{tpy})\}_{2}(\mu-\right.$ $\left.\left.\mathrm{H}_{2} \mathrm{BL}_{0}\right)\right]\left(\mathrm{PF}_{6}\right)_{6}$ [30]. Two optimized structures 2a (Fig. 1) and $2 \mathbf{b}$ (Fig. S2) were also modeled for Dye 2 based on the $\mathrm{BL}_{2}$ backbone acquired from ChemSpider database $[38,39]$ and the X-ray crystal structure of $\left\{\left[\mathrm{Ru}^{\mathrm{II}}(\mathrm{bpy})_{2}\right]_{2}\left(\mu-\mathrm{BL}_{4}\right)\right\}\left(\mathrm{ClO}_{4}\right)_{2}\left(\mathrm{BL}_{4}=\right.$ fully deprotonated indigo) [29]. Structures $\mathbf{1 a}$ and $\mathbf{2 a}$ are energetically more stable than $\mathbf{1 b}$ and $\mathbf{2 b}$, respectively (see Tables S1 and S2). Thus, this work will mainly focus on structures $\mathbf{1 a}$ and $\mathbf{2 a}$ while results pertaining to structures $\mathbf{1 b}$ and $\mathbf{2 b}$ are provided in the supplementary information (SI). Structures $\mathbf{1 a}$ and $\mathbf{2 a}$ are henceforth simply denoted as Dye 1 and Dye 2, respectively, throughout the paper. Selected geometrical parameters for Dye $\mathbf{1}$ and Dye $\mathbf{2}$ are provided in Tables 1 and S3. The ruthenium bipyridyl units are compared with related X-ray crystal structures including $\left[\mathrm{Ru}(\mathrm{bpy})_{2}\left(\mu-\mathrm{BL}_{3}\right)\right]\left(\mathrm{PF}_{6}\right)_{2}$ and $\left\{\left[\mathrm{Ru}^{\mathrm{II}}(\mathrm{bpy})_{2}\right]_{2}\left(\mu-\mathrm{BL}_{4}\right)\right\}\left(\mathrm{ClO}_{4}\right)_{2}$. Good correlation in terms of the $\mathrm{Ru}-\mathrm{N}$ bond distances and $\mathrm{N}-\mathrm{Ru}-\mathrm{N}$ bond angles is obtained between theory and experiment (see Table S4) [29,32,62-64]. The IR spectra of Dye $\mathbf{1}$ and Dye $\mathbf{2}$ are also provided in Fig. S3. Dye $1(8.127 \mathrm{D})$ is more polar than Dye $2(1.137 \mathrm{D})$ and the dipole moments of the other two structures are given in Table S5.

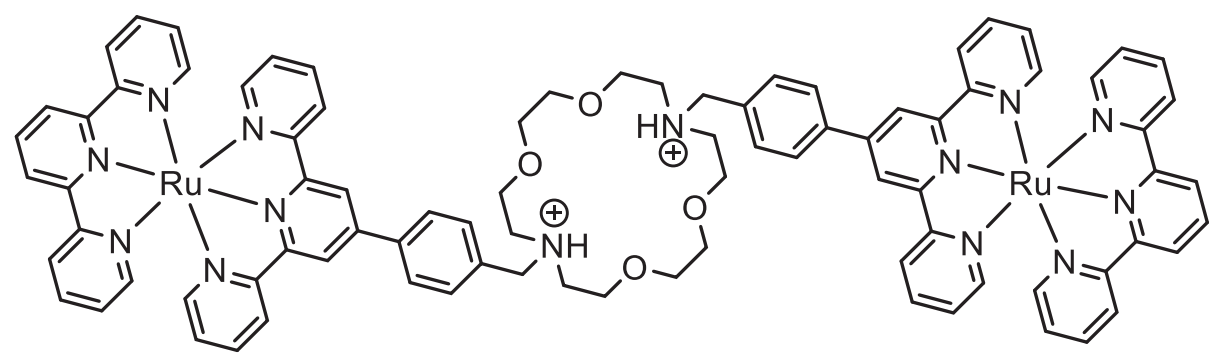

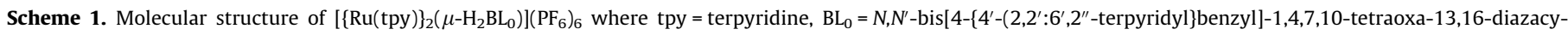
clooctadecane) and $\mathrm{PF}_{6}^{-}=$hexafluorophosphate [30]. 


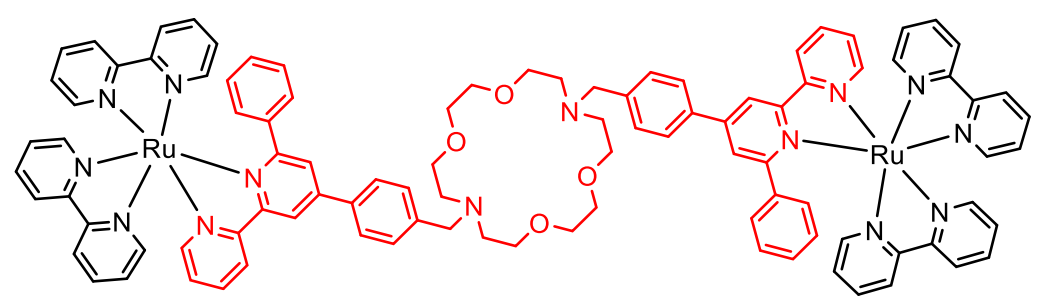

Dye 1: $\left[\left\{\mathrm{Ru}^{\mathrm{II}}(\mathrm{bpy})_{2}\right\}_{2}\left(\mu-\mathrm{BL}_{1}\right)\right]\left(\mathrm{PF}_{6}\right)_{4}$

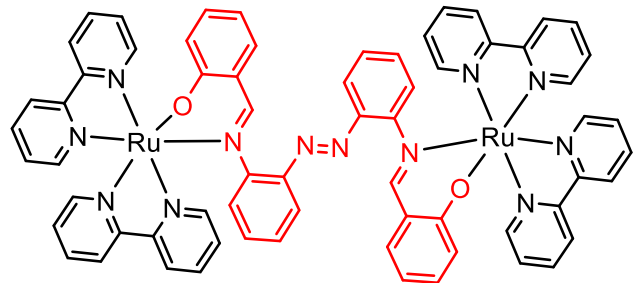

Dye 2: $\left[\left\{\mathrm{Ru}^{\mathrm{II}}(\mathrm{bpy})_{2}\right\}_{2}\left(\mu-\mathrm{BL}_{2}\right)\right]\left(\mathrm{ClO}_{4}\right)_{4}$

Scheme 2. Structures of Dye 1 and Dye 2.

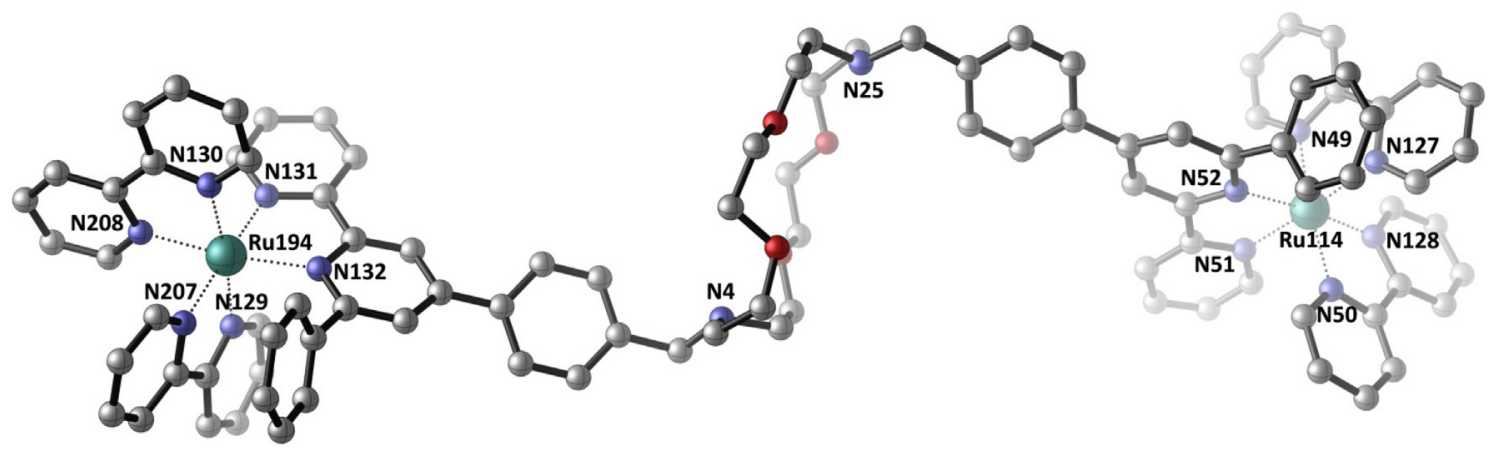

Dye 1

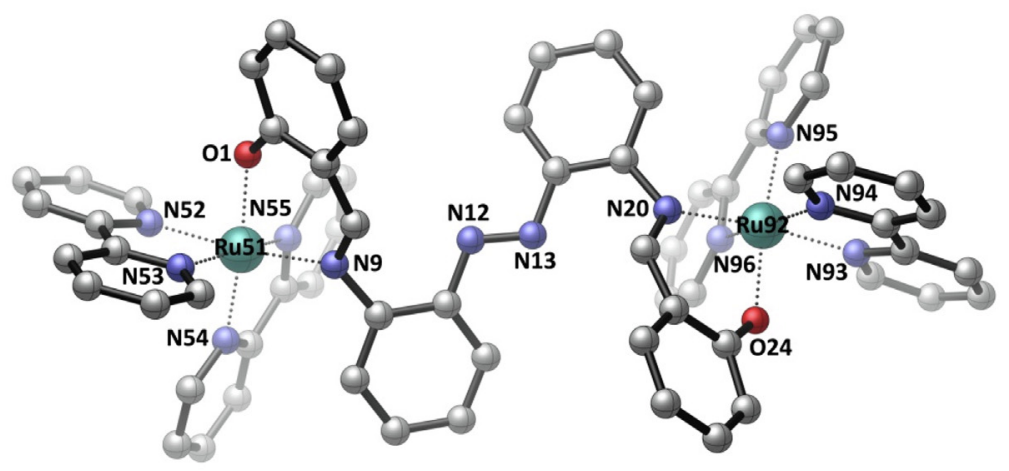

Dye 2

Fig. 1. Gas-phase optimized structures of Dye 1 and Dye 2 including atom labelling. All H atoms are omitted for clarity.

\subsection{Optical properties}

The UV-Vis spectra of the two dyes are displayed in Fig. 2. TDDFT computations were also employed to obtain the simulated UV-Vis absorption spectra for Dye 1 and Dye 2 (Figs. S4 and S5). The TD-DFT calculated electronic transition for both dyes are provided in Table 2 and Fig. S6. Dye $\mathbf{1}$ is characterized by two distinctive peaks at 288 and $455 \mathrm{~nm}$. The broader band with a peak maximum at $455 \mathrm{~nm}$ which displays the characteristics of relatively high absorptive coefficients, is ascribed to the MLCT. The simulated spectrum for Dye 1 compares satisfactorily well with the one obtained experimentally with two peaks at 328 and $415 \mathrm{~nm}$. According to the TD-DFT computations, the maximum absorption at $415 \mathrm{~nm}$ is attributed to mixed MLCT, ligand-toligand charge transfer (LLCT) and intra-ligand charge transfer (ILCT). Dye 1 is predicted to anchor to the surface of $\mathrm{TiO}_{2}$ via the pyridyl groups of the ligand, in the absence of the traditional carboxylic groups [65].

Dye 2 is characterized by two distinct peaks at 293 and $485 \mathrm{~nm}$ and one shoulder peak at $340 \mathrm{~nm}$. Absorption bands below $350 \mathrm{~nm}$ are usually ascribed to the overlapped $\pi-\pi^{*}$ ILCT while the broad band with weaker intensity from 423 to $600 \mathrm{~nm}$ is attributed to the MLCT in the complex [66-69]. The simulated spectrum for Dye 2 (Fig. S5) depicts three peaks at 358, 454 and $552 \mathrm{~nm}$. The TD-DFT computations indicate that the peak at $358 \mathrm{~nm}$ corresponds mainly to $\pi-\pi^{*}$ ILCT of the bridging ligand $\mathrm{BL}_{2}$ and MLCT $\left[\operatorname{Ru}(\mathrm{d} \pi) \rightarrow \mathrm{BL}_{2}\left(\pi^{*}\right)\right]$. A minor contribution from the LLCT and MMCT absorptions are also observed. The MLCT absorption $[\mathrm{Ru}(\mathrm{d} \pi) \rightarrow$ bpy $\left.\left(\pi^{*}\right)\right]$ and $\pi-\pi^{*}$ ILCT occurs at $454 \mathrm{~nm}$. Dye 2 anchors to the surface of $\mathrm{TiO}_{2}$ via the loose oxygen bridges of the ligand, which attach and timeously detach the surface of $\mathrm{TiO}_{2}$ based on the circumstance of the coordination environment of $\mathrm{Ru}(\mathrm{II})$ centers which 
Table 1

Selected computed geometrical parameters of Dye 1 and Dye $\mathbf{2}$ in the gas phase.

\begin{tabular}{llll}
\hline Dye 1 & \multicolumn{3}{l}{ Dye 2 } \\
\hline Bond distances $(\AA)$ & & & \\
Ru114-N49 & 2.118 & Ru51-O1 & 2.031 \\
Ru114-N50 & 2.113 & Ru51-N9 & 2.169 \\
Ru114-N51 & 2.105 & Ru51-N52 & 2.115 \\
Ru114-N52 & 2.199 & Ru51-N53 & 2.122 \\
Ru114-N127 & 2.132 & Ru51-N54 & 2.119 \\
Ru114-N128 & 2.109 & Ru51-N55 & 2.104 \\
Ru194-N129 & 2.118 & Ru92-O24 & 2.031 \\
Ru194-N130 & 2.114 & Ru92-N20 & 2.169 \\
Ru194-N131 & 2.105 & Ru92-N93 & 2.115 \\
Ru194-N132 & 2.199 & Ru92-N94 & 2.122 \\
Ru194-N207 & 2.131 & Ru92-N95 & 2.119 \\
Ru194-N208 & 2.110 & Ru92-N96 & 2.104 \\
& & & \\
Bond angles $\left(^{\circ}\right)$ & & & \\
N49-Ru114-N127 & 77.3 & O1-Ru51-N9 & 87.0 \\
N50-Ru114-N128 & 77.8 & N52-Ru51-N53 & 78.1 \\
N51-Ru114-N52 & 77.5 & N54-Ru51-N55 & 77.8 \\
N129-Ru194-N207 & 77.3 & O24-Ru92-N20 & 87.0 \\
N130-Ru194-N208 & 77.9 & N93-Ru92-N94 & 78.1 \\
N131-Ru194-N132 & 77.7 & N95-Ru92-N96 & 77.8 \\
\hline
\end{tabular}

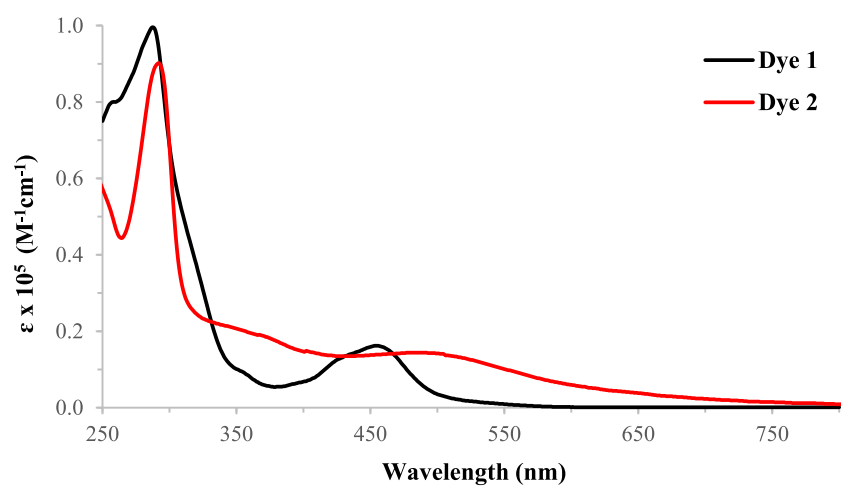

Fig. 2. Absorption spectra of Dye 1 and Dye 2, in $\mathrm{MeOH}$ both at $1 \times 10^{-5} \mathrm{M}$, room temperature.

must vary to meet the change in valence state after electrons injection into the conduction band of $\mathrm{TiO}_{2}$ [23].

The absorption spectrum shows that Dye 1 has a relatively high molar absorptivity coefficient, but with a remarkable narrow functional range (400-500 $\mathrm{nm}$ ) relatively, which are all prerequisites of a good dye sensitizer. On the other hand, Dye 2 has a low molar coefficient comparing with Dye 1, however, with a relatively redshifted broader band $(423-600 \mathrm{~nm})$, with a peak maximum at $485 \mathrm{~nm}$. Ideally, both dyes display good properties, all prerequisites to effective photon harvesting. The differences in optical behaviors for the two dyes may be ascribed to their different molecular structures, stemming from the nature of their bridging ligands, as well as the coordination circumstances of metals to the ligands.

\subsection{Electrochemical properties}

The characterization of Dye $\mathbf{1}$ by cyclic voltammetry shows cathodic oxidation peaks with blurry patterns at $0.37 \mathrm{~V}$ and $1.3 \mathrm{~V}$ for $\mathrm{Ru}^{2+}$ while an anodic reductive peak is displayed at $-1.2 \mathrm{~V}$ (Fig. 3a) versus $\mathrm{Hg} / \mathrm{Hg}_{2} \mathrm{Cl}_{2}$ reference electrode in $\mathrm{MeCN}$ containing $0.1 \mathrm{M}\left[\mathrm{N}(t-\mathrm{Bu})_{4}\right]\left(\mathrm{ClO}_{4}\right)$. The poorly resolved redox peaks are indicative of poor electronic coupling between the two ruthenium centers in Dye 1. The lack of electronic coupling is ascribed to the structure of the bridging ligand in Dye 1, where the 1,10-diaza18-crown- 4 ring acts as a barrier, rather than a $\pi$-electron system. This could be based on the fact that the size of the crown ether ring may be too large to form one huge disc-shaped $\pi$-electron cloud, which is suitable for electron tunneling. Thus, upon entering the crown ring, electrons are not propagated through but transferred back to the original ruthenium unit.

In comparison to Dye 1, the characterization of Dye 2 reveals a reversible pattern with two distinct redox peaks at 0.50 and $0.60 \mathrm{~V}$ (Fig. 3b) versus $\mathrm{Hg} / \mathrm{Hg}_{2} \mathrm{Cl}_{2}$ reference electrode in $\mathrm{MeCN}$ containing $0.1 \mathrm{M}\left[\mathrm{N}(t-\mathrm{Bu})_{4}\right]\left(\mathrm{ClO}_{4}\right)$. Two of the three redox peaks observed for Dye 2 correspond to the two-step oxidation processes: $\mathrm{Ru}^{2+}-\mathrm{BL}_{2}-$ $\mathrm{Ru}^{2+} \leftrightarrow \mathrm{Ru}^{2+}-\mathrm{BL}_{2}-\mathrm{Ru}^{3+} \leftrightarrow \mathrm{Ru}^{3+}-\mathrm{BL}_{2}-\mathrm{Ru}^{3+}$. The one remaining peak is associated with the ligand [23,24].

The HOMO-LUMO energy gaps for Dye 1 and Dye $\mathbf{2}$ were predicted in MeCN and the isodensity plot for HOMO and LUMO are provided in Fig. 4. Low-lying molecular orbitals are also provided in the SI (see Fig. S7). For Dye 1, the HOMO corresponds mainly to the $\mathrm{p}$ orbitals of the nitrogen atom of the azamacrocyclic unit and to a lesser extent to the Ru d orbitals. Its LUMO corresponds to the Ru d orbitals and to the p orbitals of the carbon and nitrogen atoms of the bpy unit as well as the terminal unit of the bridging ligand coordinated to Ru. For Dye 2, both HOMO and LUMO correspond mainly to the Ru d orbitals and the p orbitals of oxygen, carbon, and nitrogen atoms of the terminal unit of the bridging ligand. Dye $1(3.41 \mathrm{eV})$ has a significantly higher HOMO-LUMO energy gap than Dye $2(0.35 \mathrm{eV})$.

Table 2

Results of the TD-DFT computations for Dye $\mathbf{1}$ and Dye $\mathbf{2}$ in $\mathrm{MeOH}$.

\begin{tabular}{|c|c|c|c|}
\hline$\lambda_{\max }(\mathrm{nm})$ & $\begin{array}{l}\text { Oscillator } \\
\text { strength (f) }\end{array}$ & Major transitions & Character \\
\hline \multicolumn{4}{|l|}{ Dye 1} \\
\hline \multirow[t]{4}{*}{$328(288)^{\mathrm{a}}$} & 0.412 & HOMO-9 $\rightarrow$ LUMO+3 (10\%) & $\mathrm{BL}_{1}(\pi) / \operatorname{Ru}(\mathrm{d} \pi) \rightarrow \operatorname{bpy}\left(\pi^{*}\right) / \mathrm{BL}_{1}\left(\pi^{*}\right) / \operatorname{Ru}(\mathrm{d} \pi)$ \\
\hline & & HOMO-8 $\rightarrow$ LUMO (10\%) & $\mathrm{BL}_{1}(\pi) / \operatorname{Ru}(\mathrm{d} \pi) \rightarrow \operatorname{bpy}\left(\pi^{*}\right) / \operatorname{Ru}(\mathrm{d} \pi) / \mathrm{BL}_{1}\left(\pi^{*}\right)$ \\
\hline & & HOMO-7 $\rightarrow$ LUMO+6 (10\%) & $\operatorname{Ru}(\mathrm{d} \pi) / \operatorname{bpy}(\pi) / \mathrm{BL}_{1}(\pi) \rightarrow \operatorname{bpy}\left(\pi^{*}\right) / \mathrm{BL}_{1}\left(\pi^{*}\right) / \mathrm{Ru}(\mathrm{d} \pi)$ \\
\hline & & HOMO-6 $\rightarrow$ LUMO+7 (23\%) & $\operatorname{Ru}(\mathrm{d} \pi) / \operatorname{bpy}(\pi) / \mathrm{BL}_{1}(\pi) \rightarrow \operatorname{bpy}\left(\pi^{*}\right) / \mathrm{BL}_{1}\left(\pi^{*}\right) / \operatorname{Ru}(\mathrm{d} \pi)$ \\
\hline \multirow[t]{4}{*}{$415(455)$} & 0.274 & HOMO $-7 \rightarrow$ LUMO $(25 \%)$ & $\operatorname{Ru}(\mathrm{d} \pi) / \operatorname{bpy}(\pi) / \mathrm{BL}_{1}(\pi) \rightarrow \operatorname{bpy}\left(\pi^{*}\right) / \operatorname{Ru}(\mathrm{d} \pi) / \mathrm{BL}_{1}\left(\pi^{*}\right)$ \\
\hline & & HOMO-7 $\rightarrow$ LUMO+2 (19\%) & $\mathrm{Ru}(\mathrm{d} \pi) / \operatorname{bpy}(\pi) / \mathrm{BL}_{1}(\pi) \rightarrow \operatorname{bpy}\left(\pi^{*}\right) / \mathrm{BL}_{1}(\pi) / \mathrm{Ru}(\mathrm{d} \pi)$ \\
\hline & & HOMO-5 $\rightarrow$ LUMO (10\%) & $\operatorname{Ru}(\mathrm{d} \pi) / \mathrm{BL}_{1}(\pi) / \operatorname{bpy}(\pi) \rightarrow \operatorname{bpy}\left(\pi^{*}\right) / \operatorname{Ru}(\mathrm{d} \pi) / \mathrm{BL}_{1}\left(\pi^{*}\right)$ \\
\hline & & HOMO-5 $\rightarrow$ LUMO+2 (10\%) & $\mathrm{Ru}(\mathrm{d} \pi) / \mathrm{BL}_{1}(\pi) / \operatorname{bpy}(\pi) \rightarrow \operatorname{bpy}\left(\pi^{*}\right) / \mathrm{BL}_{1}(\pi) / \operatorname{Ru}(\mathrm{d} \pi)$ \\
\hline \multicolumn{4}{|l|}{ Dye 2} \\
\hline \multirow[t]{3}{*}{$358(293)$} & 0.249 & HOMO-6 $\rightarrow$ LUMO+1 (33\%) & $\operatorname{Ru}(\mathrm{d} \pi) / \mathrm{BL}_{2}(\pi) \rightarrow \mathrm{BL}_{2}\left(\pi^{*}\right) / \operatorname{Ru}(\mathrm{d} \pi)$ \\
\hline & & HOMO-5 $\rightarrow$ LUMO+1 (17\%) & $\mathrm{Ru}(\mathrm{d} \pi) / \mathrm{BL}_{2}(\pi) / \operatorname{bpy}(\pi) \rightarrow \mathrm{BL}_{2}\left(\pi^{*}\right) / \mathrm{Ru}(\mathrm{d} \pi)$ \\
\hline & & HOMO-3 $\rightarrow$ LUMO+1 (19\%) & $\operatorname{Ru}(\mathrm{d} \pi) / \mathrm{BL}_{2}(\pi) \rightarrow \mathrm{BL}_{2}\left(\pi^{*}\right) / \operatorname{Ru}(\mathrm{d} \pi)$ \\
\hline $454(340)$ & 0.065 & HOMO $\rightarrow$ LUMO+7 (93\%) & $\operatorname{Ru}(\mathrm{d} \pi) / \mathrm{BL}_{2}(\pi) \rightarrow \mathrm{BL}_{2}\left(\pi^{*}\right) / \operatorname{Ru}(\mathrm{d} \pi)$ \\
\hline $552(485)$ & 0.015 & HOMO-17 $\rightarrow$ LUMO (99\%) & $\mathrm{BL}_{2}(\pi) / \mathrm{Ru}(\mathrm{d} \pi) \rightarrow \mathrm{Ru}(\mathrm{d} \pi) / \mathrm{BL}_{2}\left(\pi^{*}\right)$ \\
\hline
\end{tabular}

\footnotetext{
a Experimental values.
} 

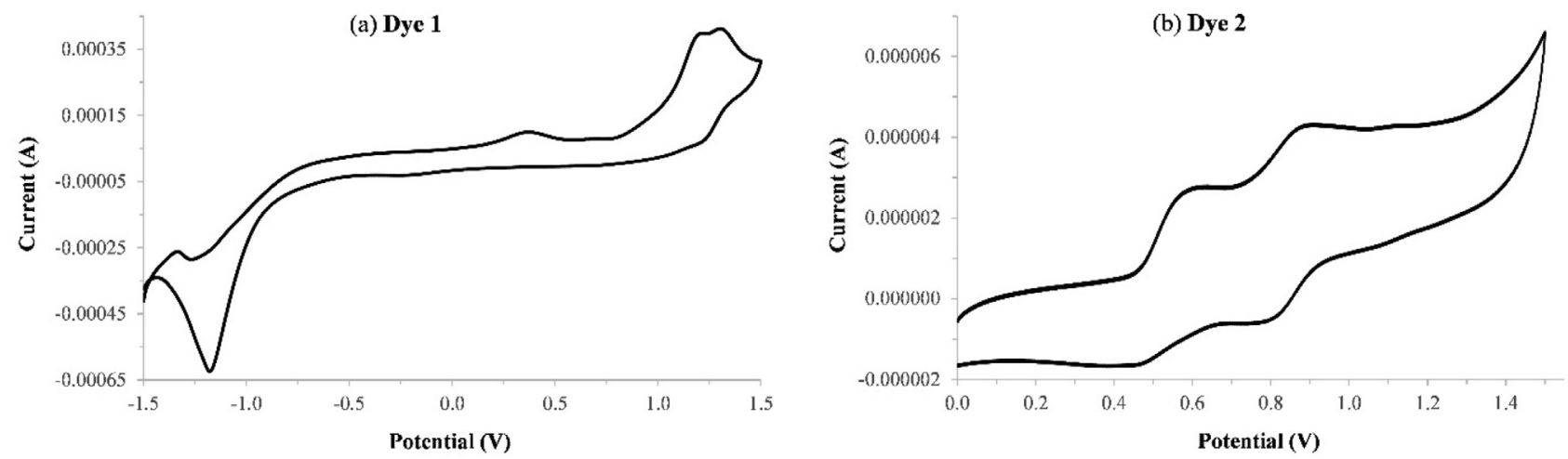

Fig. 3. The oxidative cyclic voltammogram (CV) of (a) Dye 1 and (b) Dye 2 in MeCN.
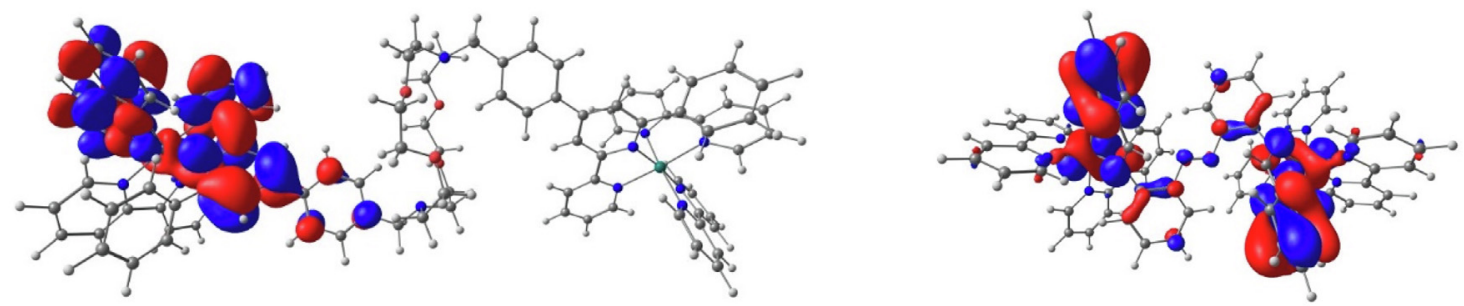

LUMO (-2.60 eV)

LUMO (-5.50 eV)

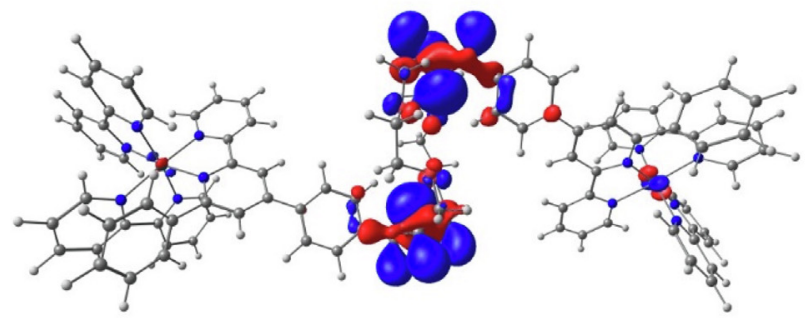

HOMO (-6.00 eV)

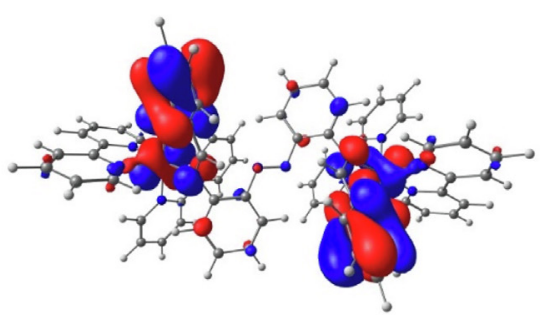

HOMO (-5.85 eV)

HOMO-LUMO gap $=3.41 \mathrm{eV}$

HOMO-LUMO gap $=0.35 \mathrm{eV}(2.27 \mathrm{eV})^{[\mathrm{a}]}$

Dye 1

Dye 2

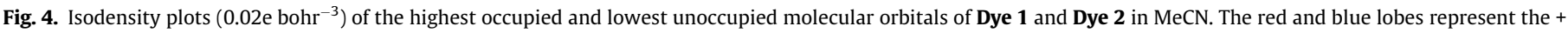
and - signs of the wavefunction, respectively. [a] Bandgap estimated by the intersection point between the normalized absorption and emission spectra.
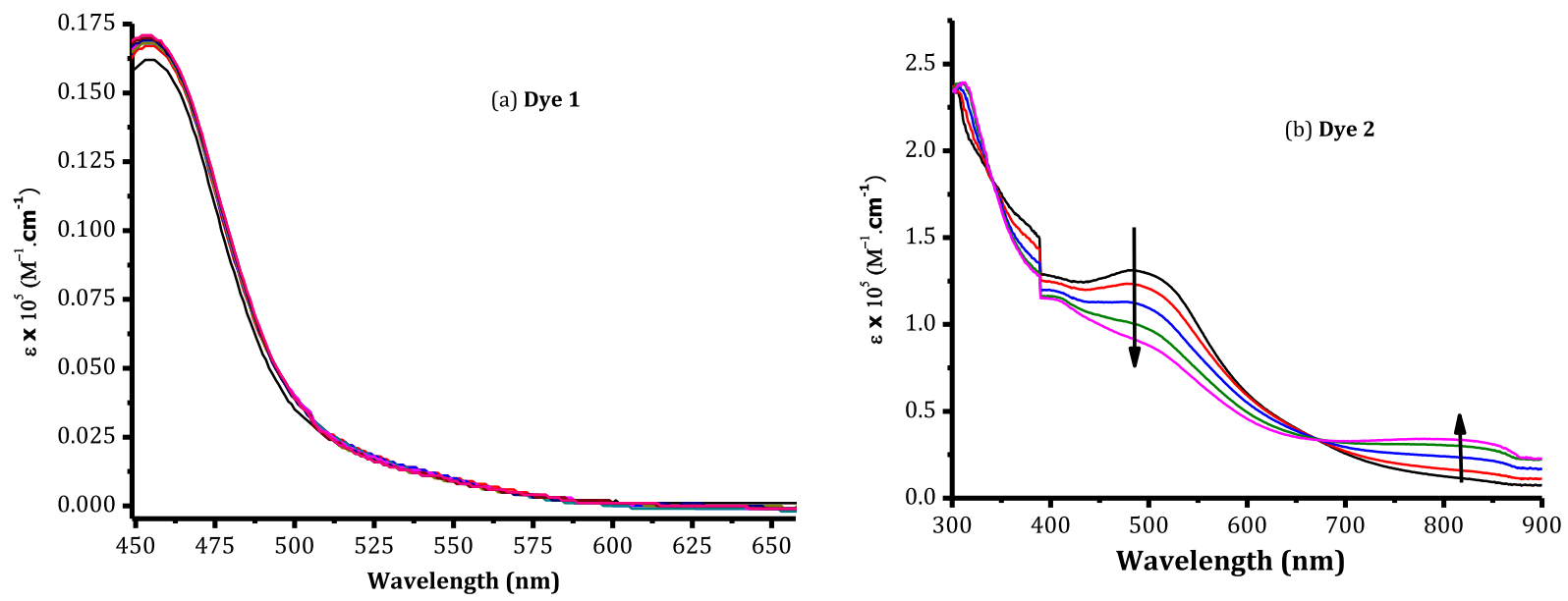

Fig. 5. The UV-Vis titration spectra of (a) Dye $1\left(1 \times 10^{-4} \mathrm{M}\right)$ in $\mathrm{MeOH}$ and (b) Dye $2\left(1 \times 10^{-5} \mathrm{M}\right)$ in EtOH, both with $\left(\mathrm{NH}_{4}\right)_{2} \mathrm{Ce}\left(\mathrm{NO}_{3}\right)_{6}$. 
UV-Vis redox titrations show comparable electronic interaction trends between the two dyes as observed from cyclic voltammetry. The redox titration of Dye $\mathbf{1}$ and $\mathrm{Ce}^{4+}$ reveals poorly resolved patterns with only one isosbestic point at about $550 \mathrm{~nm}$ (Fig. 5a), indicative of the presence of $\mathrm{Ru}^{2+}$; however, redox activities are evidently poor. This further correlates to poor electronic coupling in Dye 1 and can be attributed to the structure of the bridging ligand bearing a barrier-like 1,10-diaza-18-crown-4 ring, which hampers electronic communications between the two nuclear centers.

The molar equivalent addition of $\mathrm{Ce}^{4+}$ results in (i) a decrease in the intensity associated with the MLCT absorption band of Dye 2 at $485 \mathrm{~nm}$ and (ii) the formation of a new broad peak in the near-IR region at $750-850 \mathrm{~nm}$ (Fig. 5b). The peak in the near-IR region is usually assigned to ligand-to-metal charge transfer (LMCT) from the $\pi$-electrons of the ligand (bpy) to the excited state ruthenium center $\left(\mathrm{Ru}^{3+}\right)$. Two distinctive isosbestic points at 340 and $668 \mathrm{~nm}$ are clearly visible. This indicates that two ruthenium oxidation states $\left(\mathrm{Ru}^{2+}\right.$ and $\left.\mathrm{Ru}^{3+}\right)$ exist and hence, the presence of charge transfers (MLCT and LMCT). Electronic coupling is excellent in the azo-based bridging ligand of Dye 2, where the two coupled nitrogen atoms (with a very strong $\pi$-electronic system) link to the two ruthenium units, thus enhancing smooth electronic communications between the two centers.

\section{Conclusions}

A dinuclear ruthenium bipyridyl complex with a 1,10-diaza18-crown-6 bridging ligand (Dye 1) was synthesized and characterized. Its photophysical and electrochemical properties were studied using UV-Vis spectroscopy, cyclic voltammetry, and DFT computations. Dye 1 was compared with a related dye which is based on an azo bridge (Dye 2). UV-Vis spectroscopic analysis shows that both dyes exhibit prerequisites necessary for a good dye sensitizer. However, electrochemical analysis reveals smooth electronic coupling between the two metal centers of Dye 2 as compared to Dye 1. The bridging ligand of Dye 1 which bears the azacrown ether ring hampers the electronic communications between the two nuclear centers.

\section{Acknowledgements}

This work was supported by the Research and Publication Unit (No: URPC/2014/153) of the University of Namibia, Namibia, Royal Society-DFID Africa Capacity Building Initiative, Cardiff University, UK, Artee project engineers, Windhoek, Namibia, The National Natural Science Foundation of China (No. 21101121), the Natural Science Fund (2010CDB01301) of Hubei Province and Dalian University of Technology State Key Laboratory of Fine Chemicals Fund (KF0912). The authors also acknowledge facilities from the University of Mauritius. SEAGrid (http://www.seagrid.org) is acknowledged for computational resources and services for the selected results used in this work.

\section{Appendix A. Supplementary data}

Supplementary data to this article can be found online at https://doi.org/10.1016/j.poly.2019.114106.

\section{References}

[1] L. Spiccia, G.B. Deacon, C.M. Kepert, Synthetic routes to homoleptic and heteroleptic ruthenium(II) complexes incorporating bidentate imine ligands, Coord. Chem. Rev. 248 (2004) 1329, https://doi.org/10.1016/j.ccr.2004.04.008.

[2] B. Pashaei, H. Shahroosvand, M. Graetzel, M.K. Nazeeruddin, Influence of ancillary ligands in dye-sensitized solar cells, Chem. Rev. 116 (2016) 9485, https://doi.org/10.1021/acs.chemrev.5b00621.
[3] L. Xu, C.-L. Ho, L. Liu, W.-Y. Wong, Molecular/polymeric metallaynes and related molecules: Solar cell materials and devices, Coord. Chem. Rev. 373 (2018) 233, https://doi.org/10.1016/j.ccr.2017.10.015.

[4] United States Energy Information Administration, International Energy Outlook 2017, US Energy Information Administration 2017 Washington DC, USA [online] www.eia.gov/outlooks/ieo (Accessed 29 November 2017)

[5] A. Hagfeldt, G. Boschloo, L. Sun, L. Kloo, H. Pettersson, Dye-sensitized solar cells, Chem. Rev. 110 (2010) 6595, https://doi.org/10.1021/cr900356p.

[6] X. Zhang, T. Peng, S. Song, Recent advances in dye-sensitized semiconductor systems for photocatalytic hydrogen production, J. Mater. Chem. A 4 (2016) 2365, https://doi.org/10.1039/c5ta08939e.

[7] B. O'regan, M. Gratzel, A low-cost, high-efficiency solar cell based on dyesensitized colloidal $\mathrm{TiO}_{2}$ films, Nature 353 (1991) 737, https://doi.org/10.1038/ $353737 \mathrm{a} 0$.

[8] Z. Hosseini, N. Taghavinia, E.W.-G. Diau, Diau luminescent spectral conversion to improve the performance of dye-sensitized solar cells, ChemPhysChem 18 (2017) 3292, https://doi.org/10.1002/cphc.201700920.

[9] V.S. Mane, A.S. Kumbhar, R.P. Thummel, A ruthenium water oxidation catalyst containing a bipyridine glycoluril ligand, Dalton Trans. 46 (2017) 12901, https://doi.org/10.1039/c7dt02485a.

[10] T. Ono, S. Qu, C. Gimbert-Suriñach, M.A. Johnson, D.J. Marell, J. Benet-Buchholz, C.J. Cramer, A. Llobet, Hydrogenative carbon dioxide reduction catalyzed by mononuclear ruthenium polypyridyl complexes: discerning between electronic and steric effects, ACS Catal. 7 (2017) 5932, https://doi.org/ 10.1021/acscatal.7b00603.

[11] F. Li, J.G. Collins, F.R. Keene, Ruthenium complexes as antimicrobial agents, Chem. Soc. Rev. 44 (2015) 2529, https://doi.org/10.1039/c4cs00343h.

[12] L. Zeng, P. Gupta, Y. Chen, E. Wang, L. Ji, H. Chao, Z.-S. Chen, The development of anticancer ruthenium(II) complexes: from single molecule compounds to nanomaterials, Chem. Soc. Rev. 46 (2017) 5771, https://doi.org/10.1039/ c7cs00195a.

[13] A. Notaro, G. Gasser, Monomeric and dimeric coordinatively saturated and substitutionally inert $\mathrm{Ru}(\mathrm{II})$ polypyridyl complexes as anticancer drug candidates, Chem. Soc. Rev. 46 (2017) 7317, https://doi.org/10.1039/ c7cs00356k.

[14] F. Odobel, Y. Pellegrin, J. Warnan, Bio-inspired artificial light-harvesting antennas for enhancement of solar energy capture in dye-sensitized solar cells, Energy Environ. Sci. 6 (2013) 2041, https://doi.org/10.1039/c3ee24229c.

[15] B.L. M'Sabah, M. Boucharef, J. Warnan, Y. Pellegrin, E. Blart, B. Lucas, F. Odobel J. Boucle, Amplification of light collection in solid-state dye-sensitized solar cells via the antenna effect through supramolecular assembly, Phys. Chem. Chem. Phys. 17 (2015) 9910, https://doi.org/10.1039/c4cp05712k.

[16] E.A. Fellows, F.R. Keene, Influence of anions on intervalence charge transfer (IVCT) in mixed-valence dinuclear complexes, J. Phys. Chem. B 111 (2007) 6667, https://doi.org/10.1021/jp068203i.

[17] Z. Liu, K. Gao, B. Wan, H. Yan, P. Xing, C. Zhong, Y. Xu, H. Li, J. Chen, W. Wang, S Sun, A dinuclear ruthenium(II) complex as turn-on luminescent probe for hypochlorous acid and its application for in vivo imaging, Sci. Rep. 6 (2016), https://www.nature.com/articles/srep29065 29065.

[18] K. Barthelmes, M. Jäger, J. Kübel, C. Friebe, A. Winter, M. Wächtler, B. Dietzek, U.S. Schubert, Efficient energy transfer and metal coupling in cyanide-bridged heterodinuclear complexes based on (bipyridine)(terpyridine)ruthenium(II) and (phenylpyridine)iridium(III) complexes, Inorg. Chem. 55 (2016) 5152, https://doi.org/10.1021/acs.inorgchem.5b02919.

[19] M.T. Indelli, T. Bura, R. Ziessel, p-Carborane-bridged bipyridine ligands for energy transfer between two iridium centers, Inorg. Chem. 52 (2013) 2918, https://doi.org/10.1021/ic302222q.

[20] P. Cai, M.-X. Li, C.-Y. Duan, F. Lu, D. Guo, Q.-J. Meng, Syntheses, crystal structure and electrochemical properties of dinuclear ruthenium complexes containing saturated and unsaturated spacers, New J. Chem. 29 (2005) 1011, https://doi. org/10.1039/b502656c.

[21] T. Peng, D. Ke, P. Cai, K. Dai, L. Ma, L. Zan, Influence of different ruthenium(II) bipyridyl complex on the photocatalytic $\mathrm{H}_{2}$ evolution over $\mathrm{TiO}_{2}$ nanoparticles with mesostructures, J. Power Sources 180 (2008) 498, https://doi.org/ 10.1016/j.jpowsour.2008.02.002.

[22] N. Vilá, Y.-W. Zhong, J.C. Henderson, H.D. Abruña, Anthracene-bridged binuclear ruthenium complexes: electrochemical and spectroscopic evidence of electronic communication through the $\pi$ system, Inorg. Chem. 49 (2010) 796, https://doi.org/10.1021/ic900100w.

[23] X. Zhang, U. Veikko, J. Mao, P. Cai, T. Peng, Visible-light-induced photocatalytic hydrogen production over binuclear $\mathrm{Ru}(\mathrm{II})$-bipyridyl dye-sensitized $\mathrm{TiO}_{2}$ without noble metal loading, Chem. Eur. J. 18 (2012) 12103, https://doi.org/ $10.1002 /$ chem.201200725.

[24] V. Uahengo, X. Zhang, T. Peng, P. Cai, G. Cheng, The synthesis and characterization of dinuclear ruthenium sensitizers and their applications in photocatalytic hydrogen production, Spectrochim. Acta A, Mol. Biomol. Spectrosc. 105 (2013) 539, https://doi.org/10.1016/j.saa.2012.12.061.

[25] G.-Y. Li, J.-P. Liu, H.-Y. Huang, Y. Wen, H. Chao, L.-N. Ji, Colorimetric and luminescent dual-signaling responsive probing of thiols by a ruthenium(II)azo complex, J. Inorg. Biochem. 121 (2013) 108, https://doi.org/10.1016/j. jinorgbio.2012.12.019.

[26] H.S. Das, D. Schweinfurth, J. Fiedler, M.M. Khusniyarov, S.M. Mobin, B. Sarkar, Tuning the electronic properties in ruthenium-quinone complexes through metal coordination and substitution at the bridge, Chem. Eur. J. 20 (2014) 4334, https://doi.org/10.1002/chem.201204379. 
[27] M.A. Ansari, A. Mandal, A. Paretzki, K. Beyer, J. Fiedler, W. Kaim, G.K. Lahiri, 1,5Diamido-9,10-anthraquinone, a centrosymmetric redox-active bridge with two coupled $\beta$-ketiminato chelate functions: symmetric and asymmetric diruthenium complexes, Inorg. Chem. 55 (2016) 5655, https://doi.org/ 10.1021/acs.inorgchem.6b00726.

[28] A.S. Hazari, A. Mandal, K. Beyer, A. Paretzki, W. Kaim, G.K. Lahiri, Metal-metal bridging using the DPPP dye system: electronic configurations within multiple redox series, Inorg. Chem. 56 (2017) 2992, https://doi.org/10.1021/acs. inorgchem.6b03112.

[29] M. Chatterjee, P. Mondal, K. Beyer, A. Paretzki, W. Kaim, G.K. Lahiri, A structurally characterised redox pair involving an indigo radical: indigo based redox activity in complexes with one or two $\left[\mathrm{Ru}(\mathrm{bpy})_{2}\right]$ fragments, Dalton Trans. 46 (2017) 5091, https://doi.org/10.1039/c7dt00055c.

[30] B. Whittle, S.R. Batten, J.C. Jeffery, L.H. Rees, M.D. Ward, Ruthenium(II) complexes of some new polynucleating ligands incorporating terpyridyl and macrocyclic aza-crown binding sites, J. Chem. Soc., Dalton Trans. (1996) 4549, https://doi.org/10.1039/DT9960004249.

[31] K.L. Bushell, S.M. Couchman, J.C. Jeffery, L.H. Rees, M.D. Ward, Stepwise synthetic strategy for the preparation of trinuclear complexes of bis (terpyridyl) bridging ligands containing aza-crown macrocyclic spacer groups, J. Chem. Soc., Dalton Trans. (1998) 3397, https://doi.org/10.1039/ A805059G.

[32] S. Encinas, K.L. Bushell, S.M. Couchman, J.C. Jeffery, M.D. Ward, L. Flamigni, F. Barigelletti, Switching of the inter-component photoinduced electron- and energy-transfer properties of a $\mathrm{Ru}(\mathrm{II})$-aza-crown-Re(I) complex; effects of changing temperature, and of incorporation of $\mathrm{Ba}^{2+}$ ion into the macrocyclic spacer between the chromophores, J. Chem. Soc., Dalton Trans. (2000) 1783, https://doi.org/10.1039/B001594F.

[33] R.L. Paul, A.F. Morales, G. Accorsi, T.A. Miller, M.D. Ward, F. Barigelletti, Modulation of photoinduced energy-transfer between $\mathrm{Ru}(\mathrm{II})$ and $\mathrm{Os}$ (II) termini in a dinuclear complex by a conformational change induced by $\mathrm{Ba}^{2+}$ binding at a central macrocyclic site, Inorg. Chem. Commun. 6 (2003) 439, https://doi. org/10.1016/S1387-7003(03)00008-X.

[34] S. Katariya, L. Rhyman, I.A. Alswaidan, P. Ramasami, N. Sekar, Triphenylaminebased fluorescent styryl dyes: DFT, TD-DFT and non-linear optical property study, J. Fluoresc. 27 (2017) 993, https://doi.org/10.1007/s10895-017-2034-1.

[35] Y. Gawale, L. Rhyman, M.I. Elzagheid, P. Ramasami, N. Sekar, Excited state and non-linear optical properties of NIR absorbing $\beta$-thiophene-fused $\mathrm{BF}_{2}$ azadipyrromethene dyes - computational investigation, J. Fluoresc. 28 (2017) 243, https://doi.org/10.1007/s10895-017-2186-Z.

[36] V. Uahengo, Y. Zhang, B. Xiong, P. Zhao, P. Cai, L. Rhyman, P. Ramasami, K. Hu, G. Cheng, A fluoro-chromogenic sensor based on organic molecular framework for $\mathrm{Cu}^{2+}$ and $\mathrm{F}^{-}$in aqueous soluble DMSO, J. Fluoresc. 27 (2017) 191, https:// doi.org/10.1007/s10895-016-1945-6.

[37] S. Welter, N. Salluce, P. Belser, M. Groeneveld, L. De Cola, Photoinduced electronic energy transfer in modular, conjugated, dinuclear $\mathrm{Ru}(\mathrm{II}) / \mathrm{Os}(\mathrm{II})$ complexes, Coord. Chem. Rev. 249 (2005) 1360, https://doi.org/10.1016/j. ccr.2004.11.008.

[38] H.E. Pence, A. Williams, ChemSpider: an online chemical information resource, J. Chem. Educ. 87 (2010) 1123, https://doi.org/10.1021/ed100697w.

[39] http://www.chemspider.com/Chemical-Structure.28291026.html [Accessed 26 November 2017]

[40] H.B. Schlegel, Optimization of equilibrium geometries and transition structures, J. Comput. Chem. 3 (1982) 214, https://doi.org/10.1002/ jcc.540030212.

[41] H.B. Schlegel, in: D.R. Yarkony, (ed.) Modern Electronic Structure Theory; World Scientific Publishing: Singapore, 1995, p. 459.

[42] V. Barone, M. Cossi, Quantum calculation of molecular energies and energy gradients in solution by a conductor solvent model, J. Phys. Chem. A 102 (1998) 1995, https://doi.org/10.1021/jp9716997.

[43] M. Cossi, V. Barone, Time-dependent density functional theory for molecules in liquid solutions, J. Chem. Phys. 115 (2001) 4708, https://doi.org/10.1063/ 1.1394921.

[44] M. Cossi, N. Rega, G. Scalmani, V. Barone, Energies, structures, and electronic properties of molecules in solution with the C-PCM solvation model, J. Comput. Chem. 24 (2003) 669, https://doi.org/10.1002/jcc.10189.

[45] A.D. Becke, Density-functional thermochemistry. III. The role of exact exchange, J. Chem. Phys. 98 (1993) 5648, https://doi.org/10.1063/1.464913.

[46] C. Lee, W. Yang, R.G. Parr, Development of the Colle-Salvetti correlation-energy formula into a functional of the electron density, Phys. Rev. B 37 (1988) 785, https://doi.org/10.1103/PhysRevB.37.785.

[47] P.J. Stephens, F.J. Devlin, C.F. Chabalowski, M.J. Frisch, Ab initio calculation of vibrational absorption and circular dichroism spectra using density functional force fields, J. Phys. Chem. 98 (1994) 11623, https://doi.org/10.1021/ j100096a001.
[48] W.J. Hehre, L. Radom, P.v.R. Schleyer, J. Pople, Ab Initio Molecular Orbital Theory, Wiley, New York, 1986.

[49] P.J. Hay, W.R. Wadt, Ab initio effective core potentials for molecular calculations. Potentials for $\mathrm{K}$ to Au including the outermost core orbitals, J. Chem. Phys. 82 (1985) 299, https://doi.org/10.1063/1.448975.

[50] P. Dreyse, B. Loeb, M. Soto-Arriaza, D. Tordera, E. Ortí, J.J. Serrano-Pérez, H.J. Bolink, Effect of free rotation in polypyridinic ligands of $\mathrm{Ru}(\mathrm{II})$ complexes applied in light-emitting electrochemical cells, Dalton Trans. 42 (2013) 15502, https://doi.org/10.1039/c3dt52067f.

[51] F. Scalambra, M. Serrano-Ruiz, S. Nahim-Granados, A. Romerosa, Ruthenium complexes containing 2,2'-bipyridine and 1,3,5-triaza-7-phosphaadamantane, Eur. J. Inorg. Chem. 2016 (2016) 1528, https://doi.org/10.1002/ejic. 201501357.

[52] P. Ghosh, S. Banerjee, G.K. Lahiri, Ruthenium derivatives of in situ generated redox-active 1,2-dinitrosobenzene and 2-nitrosoanilido. Diverse structural and electronic forms, Inorg. Chem. 55 (2016) 12832, https://doi.org/10.1021/ acs.inorgchem.6b02197.

[53] S.-H. Wu, J.-Y. Shao, X. Dai, X. Cui, H. Su, Y.-W. Zhong, Synthesis and characterization of tris(bidentate) ruthenium complexes of di(pyrid-2-yl) (methyl)amine, Eur. J. Inorg. Chem. (2017) 3064, https://doi.org/10.1002/ ejic.201700291.

[54] R. Bauernschmitt, R. Ahlrichs, Treatment of electronic excitations within the adiabatic approximation of time dependent density functional theory, Chem. Phys. Lett. 256 (1996) 454, https://doi.org/10.1016/0009-2614(96)00440-X.

[55] F. Furche, D. Rappoport, Density functional methods for excited states: equilibrium structure and electronic spectra, Theor. Comput. Chem. 16 (2005) 93, https://doi.org/10.1016/S1380-7323(05)80020-2.

[56] M.J. Frisch et al., Gaussian 09, Revision D.01, Gaussian Inc., Wallingford CT, 2009.

[57] S. Pamidighantam, S. Nakandala, E. Abeysinghe, C. Wimalasena, S. Rathnayakae, S. Marru, M. Pierce, Community science exemplars in SEAGrid science gateway: Apache Airavata based implementation of advanced infrastructure, Procedia Comput. Sci. 80 (2016) 1927, https://doi.org/ 10.1016/j.procs.2016.05.535.

[58] N. Shen, Y. Fan, S. Pamidighantam, E-science Infrastructures for molecular modeling and parametrization, J. Comput. Sci. 5 (2014) 576, https://doi.org/ 10.1016/j.jocs.2014.01.005.

[59] R. Dooley, K. Milfeld, C. Guiang, S. Pamidighantam, G. Allen, From proposal to production: lessons learned developing the computational chemistry grid cyberinfrastructure, J. Grid Comput. 4 (2006) 195, https://doi.org/10.1007/ s10723-006-9043-7.

[60] K. Milfeld, C. Guiang, S. Pamidighantam, J. Giuliani, Cluster computing through an application-oriented computational chemistry grid, Proceedings of the 2005 Linux Clusters: The HPC Revolution, 2005.

[61] This work used the Extreme Science and Engineering Discovery Environment (XSEDE), which is supported by National Science Foundation grant number OCI-1053575.

[62] E.Y. Cheung, K. Fujii, F. Guo, K.D.M. Harris, S. Hasebe, R. Kuroda, Structural chemistry of a new chiral anhydrous phase of $\mathrm{Ru}(\mathrm{bipy})_{3}\left(\mathrm{ClO}_{4}\right)_{2}$ established from powder X-ray diffraction analysis, Cryst. Growth Des. 11 (2011) 3313, https://doi.org/10.1021/cg200379h.

[63] M.J. Fuentes, R.J. Bognanno, W.G. Dougherty, W.J. Boyko, W.S. Kassel, T.J. Dudley, J.J. Paul, Structural, electronic and acid/base properties of [Ru(bpy $\left.\left.(\mathrm{OH})_{2}\right)_{3}\right]^{2+}\left(\mathrm{bpy}(\mathrm{OH})_{2}=4,4^{\prime}\right.$-dihydroxy-2,2'-bipyridine), Dalton Trans. 41 (2012) 12514, https://doi.org/10.1039/c2dt31706k.

[64] R. Puttreddy, J.A. Hutchison, Y. Gorodetski, J. Harrowfield, K. Rissanen, Enantiomer separation of tris(2,2'-bipyridine)ruthenium(II): interaction of a $D_{3}$-symmetric cation with a $C_{2}$-symmetric anion, Cryst. Growth Des. 15 (2015) 1559, https://doi.org/10.1021/acs.cgd.5b00053.

[65] Y. Ooyama, N. Yamaguchi, I. Imae, K. Komaguchi, J. Ohshita, Y. Harima, Dyesensitized solar cells based on D-p-A fluorescent dyes with two pyridyl groups as an electron withdrawing-injecting anchoring group, Chem. Commun. 49 (2013) 2548, https://doi.org/10.1039/c3cc40498f.

[66] E. Bae, W. Choi, Effect of the anchoring group (carboxylate vs phosphonate) in Ru-complex-sensitized $\mathrm{TiO}_{2}$ on hydrogen production under visible light, J. Phys. Chem. B 110 (2006) 14792, https://doi.org/10.1021/jp062540+.

[67] M. Abrahamsson, O. Taratula, P. Persson, E. Galoppini, G.J. Meyer, Metasubstituted $\mathrm{Ru}^{\mathrm{II}}$ rigid rods for sensitization of $\mathrm{TiO}_{2}$, J. Photochem. Photobiol. A: Chem. 206 (2009) 155, https://doi.org/10.1016/j.jphotochem.2009.06.002.

[68] A.S.F. Farinha, A.C. Tomé, J.A.S. Cavaleiro, Synthesis of new calix[4]pyrrole derivatives via 1,3-dipolar cycloadditions, Tetrahedron 66 (2010) 7595, https://doi.org/10.1016/j.tet.2010.07.024.

[69] M.K. Nazeeruddin, S.M. Zakeeruddin, J.J. Lagref, P. Liska, P. Comte, C. Barolo, G. Viscardi, K. Schenk, M. Graetzel, Stepwise assembly of amphiphilic ruthenium sensitizers and their applications in dye-sensitized solar cell, Coord. Chem. Rev. 248 (2004) 1317, https://doi.org/10.1016/j.ccr.2004.03.012. 